\title{
ANALISIS HADIST TARBAWY TENTANG MATERI PEMBELAJARAN AGAMA ISLAM (KAJIAN HADIST KONTEMPORER)
}

\author{
Nurul Hidayah ${ }^{* 1}$ \\ 1Pendidikan Bahasa Arab \\ Universitas KH. A. Wahab Hasbullah Jombang \\ Email: nurulhidayah@unwaha.ac.id \\ Khusnul Khotimah ${ }^{2}$ \\ 2Pendidikan Agama Islam \\ Universitas KH. A. Wahab Hasbullah Jombang \\ Email: khusnulkhotimah6236@gmail.com
}

\begin{abstract}
Islamic learning materials are important as stimulation to students. Knowledge of the teachings has been systematically discussed in islamic sciences, each of which emphasizes certain aspects of the teaching. Islamic learning materials are very basic and important for the development of learners, because in fact educators not only transfer knowledge, but also the heirs of culture and values so as to make human character in accordance with the Qur'an and As-Sunnah. In this case, this study aims to explain the islamic material contained in the Hadith Tarbawy. This study uses descriptive qualitative research that explores as deeply as possible islamic learning materials from the study of Hadith Tarbawy, this type of research is a research library (library research). This research, collection techniques are done using documentation methods, namely by searching for data or information from books, books and other records. It is then analyzed using miles and hybermen models. The results of this study explain: (1). Aqidah material is a material that explains, that the place of asking and complaining only to Allah swt. (2). The material of the Qur'an is a material that explains, about the study of reading the Qur'an and tajwid, the nature and makhrajnya ma'na and its interpretation. (3). Figh material is a material that explains the rules of Islam and knows halal and haraam, the laws concerning worship and muamalah. So it can be concluded that the three materials can not be separated, because in fact matri Aqidah, Qur'an, Figh is very important in terms of daily life.
\end{abstract}

Keywords: Hadith Tarbawy, Learning Materials, Contemporary Hadith Studies.

\begin{abstract}
Abstrak
Materi pembelajaran Agama Islam merupakan hal yang penting sebagai stimulasi terhadapa peserta didik. Pengetahuan tentang ajaran tersebut, secara sistematis telah dibahas dalam ilmuilmu keislaman, yang masing-masing menekankan pada aspek ajaran tertentu. Materi-materi pembelajaran Agama Islam merupakan hal yang sangat pokok dan penting bagi perkembangan peserta didik, karena pada hakikatnya pendidik tidak hanya transfer pengetahuan saja, tetapi
\end{abstract}




\section{Nurul Hidayah, Khusnul Khotimah.}

juga pewaris budaya dan nilai sehingga menjadikan manusia yang berkarakter sesuai dengan Al-Qur'an dan As-Sunnah. Dalam hal tersebut, maka penelitian ini bertujuan untuk menjelaskan materi Agama Islam yang terdapat dalam Hadist Tarbawy. Penelitian ini menggunakan penelitian kualitatif deskriptif yang menggali sedalam mungkin materi pembelajaran Agama Islam dari kajian Hadist Tarbawy, jenis penelitian ini adalah peneltian kepustakaan (library research). Penelitian ini, teknik pengumpulan dilakukan dengan menggunakan metode dokumentasi, yakni dengan cara mencari data atau informasi dari kitabkitab, buku-buku dan catatan-catatan lainnya. Kemudian dianalisis menggunakan model miles dan hybermen. Hasil penelitian ini menjelaskan: (1). Materi Aqidah ialah materi yang menjelaskan, bahwa tempat meminta dan mengadu hanyala kepada Allah swt. (2). Materi AlQur'an ialah materi yang menjelaskan, tentang pengkajian membaca Al-Qur'an dan tajwid, sifat dan makhrajnya ma'na dan tafsirannya. (3). Materi Fiqih ialah materi yang menjelaskan tentang kaidah-kaidah Islam dan mengetahui halal dan haram, hukum-hukum mengenai ibadah dan muamalah. Maka dapat disimpulkan bahwa ketiga materi tersebut tidak dapat dipisahkan, karena pada hakikatnya matri Aqidah, Al-Qur'an, Fiqih itu sangatlah penting dalam hal kehidupan sehari-hari.

Kata kunci: Hadist Tarbawy, Materi Pembelajaran, Kajian Hadist Kontemporer.

\section{A. PENDAHULUAN}

Pembelajaran Agama Islam adalah upaya sadar dan terencana dalam menyiapkan peserta didik untuk mengenal, memahami, menghayati, mengimani, bertakwa, berakhlak mulia, mengamalkan ajaran agama Islam dari sumber utamanya kitab suci Al-Qur'an dan Al-Hadits, melalui kegiatan bimbingan, pengajaran latihan, serta penggunaan pengalaman. Setiap manusia yang diciptakan oleh Allah SWT agar dapat menjalankan dan mengamalkan ajaran agama islam dalam kehidupannya sehari-hari sebagai ibadah kepada Allah swt.

Menurut Zakiah Darajat, Pembelajaran Agama Islam, adalah Pembelajaran dengan melalui ajaran-ajaran Agama Islam, yaitu berupa bimbingan ddan asuhan terhadap anak didik agar nantinya setelah selesai dari pendidikan ia dapat memahami, menghayati, dan mengamalkan ajaran-ajaran agama Islam 
yang telah diyakininya secara menyeluruh, serta menjadikan ajaran Agama Islam itu sebagai suatu pandangan hidupnya demi keselamatan dan kesejahteraan hidup di dunia dan di akhirat kelak.

Hadist merupakan salah satu dasar pembelajaran Islam selain al-Qur'an. Dimana dasar adalah suatu yang pentingbagi sebuah kerangka pembelajaran Islam. Karena pada hakikatnya dasar sebagai landasan untuk berdirinya sesuatu. Fungsi dasar ialah memberikan arah pada tujuan yang akan dicapai sekaligus sebagai modal yang pokok bagi berdirinya subuah lembaga pembelajaran Islam. Dasar pembelajaran agama islam didasarkan kepadafalsafah hidup suatu negara. Falsafah hidup umat Islam itu sendiri terletak pada dua sumber pokok yaitu alQur'an dan as-Sunnah(al-hadist). ${ }^{1}$

Materi pembelajaran Agama Islam merupakan hal yang penting sebagai stimulasi terhadapa peserta didik. Pengetahuan tentang ajaran tersebut, secara sistematis telah dibahas dalam ilmu-ilmu keislaman, yang masing-masing menekankan pada aspek ajaran tertentu. Karena memiliki karakteristik yang berbeda, maka perkembangan masing-masing dimensi keberagaman tersebut juga memerlukan materi yang berbeda. ${ }^{2}$

. Berdasarkan penjabaran diatas, kegiatan pembelajaran memang sangatlah penting dalam mencapai tujuan yang diinginkan, oleh karena itu peneliti akan menjelaskan tentang “ Analisis Hadist Tarbawi Tentang Materi

\footnotetext{
${ }^{1}$ Ramayulis, Ilmu Pendidikan Islam, (Jakarta: Kalam Mulia, 2010), h.121.

${ }^{2}$ Erwin Yudi Prahara, Materi Pendidikan Agama Islam (Ponorogo: STAIN Po PRESS, 2009), h.15
} 


\section{Nurul Hidayah, Khusnul Khotimah.}

Pembelajaran Agama Islam”. Agar bisa dapat memudahkan seseorang dalam mencapai tujuannya.

\section{B. METODE PENELITIAN}

Dalam penelitian ini peneliti menggunakan pendekatan kualitatif deskriptif. Menurut Moleong yang dimaksud penelitian kualitatif adalah penelitian yang bermaksud untuk memahami fenomena tentang apa yang dialami oleh subjek penelitian secara holistik dengan cara deskripsi dalam bentuk katakata dan bahasa, pada suatu konteks khusus yang alamiah dan dengan memanfaatkan berbagai metode. ${ }^{3}$

Kirk dan Miler(1986:9) mendefisikan bahwa penelitian kualitatif adalah tradisi tertentu dalam ilmu pengetahuan social yang secara fundemental bergantung pada pengamatan pada manusia daam kawasannya sendiri dan berhubungan dengan orang-orang tersebut dalam bahasanya dan dalam peristilahannya. ${ }^{4}$

Jenis penelitian yang digunakan dalam penelitian ini adalah penelitian kepustakaan (library research), yang mengumpulkan dan menganalisis dari bahan-bahan perpustakaan, baik berupa buku-buku ataupun dokumendokumen perpustakaan lainnya ${ }^{5}$. Jenis penelitian kepustakaan ini berupa kajian hadist tentang Pembelajaran Materi Agama Islam.

\footnotetext{
${ }^{3}$ Moelong, Lexy. J, Metodologi Penelitian Kualitatif, (Bandung: Remaja Rosdakarya. 2007). h. 6

${ }^{4}$ Ibid, h. 3

${ }^{5}$ Abdurrahmat Fathoni, Metodologi Penelitian dan Teknik Penyusunan Skripsi, (Jakarta: PT. Rineka Cipta, 2006), hlm. 96
} 
Analisis data dalam penelitian ini akan menggunakan model miles dan hybermen dengan proses analisis deskriptif kualitatif, yaitu terdiri dari tiga kegiatan yaitu: pengumpulan data sekaligus reduksi data, penyajian data, dan kesimpulan atau verifikasih.

Dalam menganalisis data peneliti akan menggunakan deskriptif kualitatif. Yaitu sebagai berikut :

1. Pengumpulan Data (Dalam pengumpulan data dilakukan melalui observasi, dan dokumentasi. Data-data tersebut tersedia dari berbagai sumber seperti buku-buku, jurnal, setelah itu dikumpulkan, dibaca, dipelajari dan ditelaah, maka selanjutnya adalah mereduksi data tersebut).

2. Reduksi Data (Dalam mereduksi data ini, peneliti memfokuskan pada hal-hal yang penting yang menggolongkan data sedemikian rupa).

3. Penyajian Data ( Dalam penelitian ini,peneliti mendisplay data-data untuk memudahkan perencanaan selanjutnya).

4. Penarikan Kesimpulan dan Verifikasi (Dalam penelitian ini, peneliti hanya mengulas kembali pada catatan-catatan penjelasan yang didapat).

\section{HASIL PENELITIAN}

\section{Hadits Tentang Materi Aqidah}

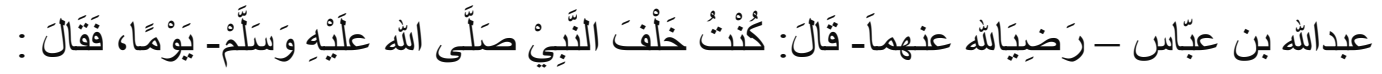

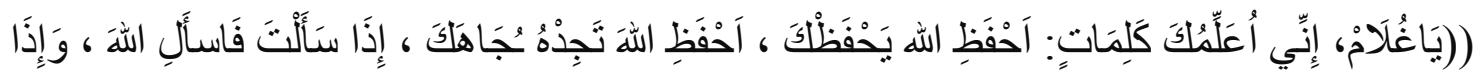

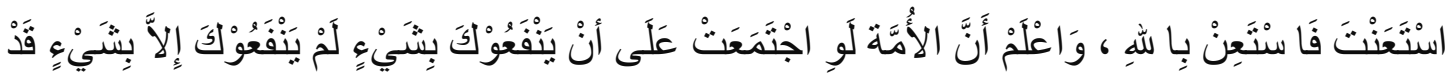




\section{Nurul Hidayah, Khusnul Khotimah.}

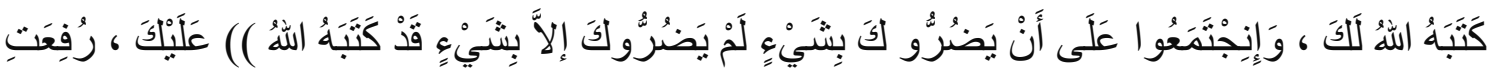

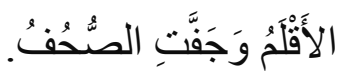

Dari 'Abdullah Bin 'Abbas ra ' : menceritakan suatu hari saya berada di belakang Nabi SAW. Beliau bersabda " Nak, aku ajarkan kepadamu beberapa untaian kalimat 'Jagalah Allah, niscaya dia akan menjagamu. Jagalah Allah, niscaya kau dapati Dia di hadapanmu. Jika engkau hendak meminta, memintalah kepada Allah, dan jika kau hendak memohon pertolongan, mohonlah kepada Allah'. Ketauhilah, seandainya seluruh umat bersatu untuk memberimu suatu keuntungan, maka hal itu tidak akan kamu peroleh selain dari apa yang telah Allah tetapkan untukmu. Dan andaipun mereka bersatu untuk melakukan suatu yang membahayakan, maka hal itu tidak akan membahayakanmu kecuali apa yang telah Allah tetapkan untuk dirimu. Pena telah diangkat dan lembaran-lembaran telah kering" . 6 (H.R. at- Tirmidzi)

Hadist tersebut menjelaskan tentang materi pembelajaran Aqidah Islam. Rasulullah menyampaikan kepada kepada Abdullah bin 'Abbas pada usia mudanya. Dalam hal ini menunjukkan bahwa pembalajaran Aqidah sudah ditanamkan kepada seseorang sejak kecil. Karena pada usia inilah yang paling tepat untuk menanamkan nilai-nilai agama Islam. Bila nilai tersebut sudah tertanam, maka kehidupan setelah dewasa dan masa tua banyak dipengaruhi oleh masa muda itu. Sehingga kalaupun seseorang hidup dilingkungan yang

${ }^{6}$ Kitab Ar ba'in an- Nawawi, Hadist ke-19 
sangat jauh dari ajaran Islam, tetapi ideologinya tidak terpengaruh, keyakinannya tidak goyah. ${ }^{7}$

Dalam pelajaran seperti ini memang sangat tepat diajarkan pada anak ${ }^{8}$ Psikologi anak mudah menerima pendidikan seperti ini dan dengan bahasa seperti hadits ini. Yang diharapkan darinya ialah, doktrin tersebut tertanam dalam benaknya sampai tua. Pada waktu ia dewasa ia tetap teringat bahwa apabila seseorang ingin senantiasa mendapat penjagaan dari Allah maka ia harus juga menjaga Allah Swt dalam kesehariannya. ${ }^{9}$

Dalam hadist tersebut juga menjelaskan bahwasanya Rasulullah saw, juga mengajarkan kepada Abdullah bin 'Abbas agar senantiasa memlihara aturan-aturan yang sudah ditetapkan oleh Allah swt. Tidak melanggar batasanbatasanya, kaluapun ini dilakukan, niscaya Allah akan memeliharaNya juga. Dan jika Allah dijaga dalam artian hukum-hukumNya ditaati, maka pada saat manusia membutuhkan bantuan Allah, maka Allah senantiasa dihadapanNya, menolong kesusahanNya, meringankan bebanNya.

\section{Hadits Tentang Materi Pembelajaran Al-Qur'an}

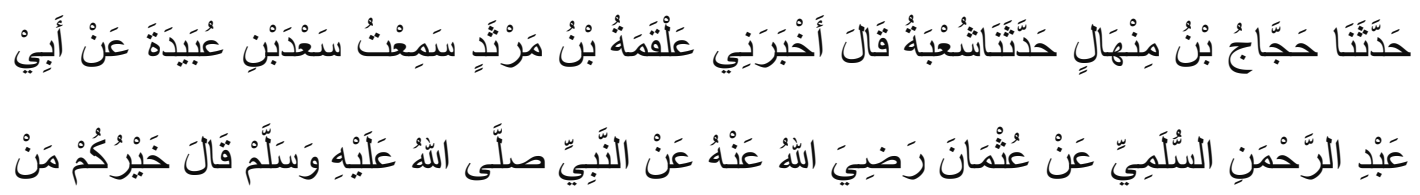

7 Juwariyah, Hadist Tarbawi, (Yogyakarta: Teras, 2010), hal. 45

${ }^{8}$ F. J. Monks (et.al), Psikologi Perkembangan Pengantar Dalam Berbagai Bagiannya, Gadjah Mada University Press, Yogyakarta, 2001, h. 87.

${ }^{9}$ Abdullah Nasih Ulwan, Pendidikan Anak Dalam Islam, terj. Jamaludin Miri, (jakarta: Pustaka Amani, 2002), h. 440 


\section{Nurul Hidayah, Khusnul Khotimah.}

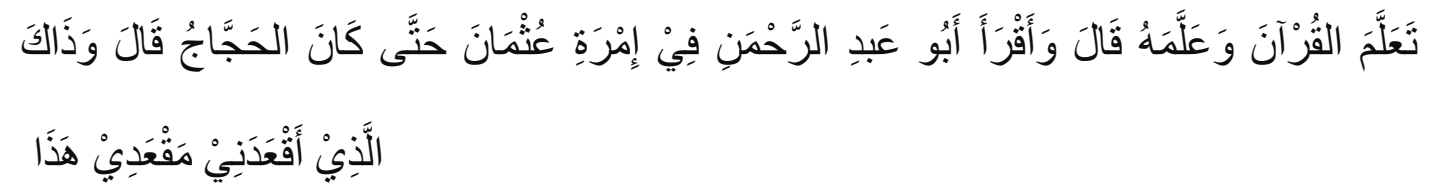

Telah menceritakan kepada kami Hajjah bin Minhal, telah menceritakan kepada kami Syu'ban ia berkata, telah mengabarkan kepadaku 'Alqamah bin Martsad Aku mendengar Sa'd bin Ubaidah dari Abdurrahman As Sulami dari Utsman r.a. dari Nabi SAW. Beliau bersabda: " Orang yang paling baik di antara kalian adalah seorang yang belajar Al-Qur'an dan mengajarkannya". Abu Abdirrahman membacakan (Al-Qur'an) pada masa Utsman hingga Hajjah pun berkata: 'Dan hal itulah yang menjadikanku duduk ditempat dudukku ini. (HR. Bukhari).

Materi pembelajaran Al-Qur'an adalah materi yang paling agung diantara sekian materi pembelajaran, karena seluruh mata pelajaran menginduk dan merujuk kepada Al-Qur'an. Semua materi pembelajaran baik agama maupun umum, sains, teknologi bersumber dari Al-Qur'an. Betapa agungnya manusia yang mau mempelajari dan mengamalkan Al-Qur'an, sebagaimana sabda Nabi yang diriwayatkan oleh al-Bukhari dari Utsman :

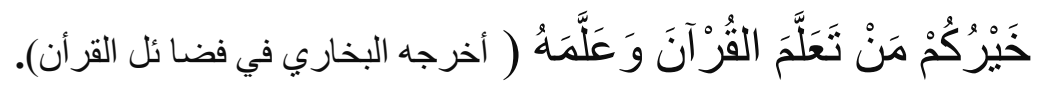

“Sebaik-baik (manusia) diantara kamu adalah yang mempelajari Al-Qur'an dan mengajarkannya 
Dalam hadist tersebut menjelaskan tentang materi pembelajaran AlQur'an. Materi pembelajaran Al-Qur'an meliputi pengajian membaca Al-Qur'an dan tajwid, sifat dan makhrajnya maupun kajian ma'na, terjemah dan tafsirnya. Pembelajaran Al-Qur'an juga memasukkan ilmu-ilmu yang dikaji dari AlQur'an baik umum ataupun agama. Para pakar pendidikan sepakat bahwa AlQur'an adalah materi pokok dalam pendidikan Islam yang harus diajarkan kepada anak didik.

Dalam pembahasan diatas dapat disimpulkan bahwa, Rasulullah dan para pendidik Muslim sangat menaruh perhatian kepada umat Islam agar belajar dan mengajarkan Al-Qur'an, mampu membaca, mampu memahami dna mengamalkannya. Al-Qur'an dijadikan pedoman hidup (way of life) dalam berbagai aspek baik dalam beribadah maupun dalam bermuamalah, bahkan AlQur'an sumber berbagai ilmu pengetahuan.

\section{Hadits Tentang Materi Pembelajaran Fiqih}

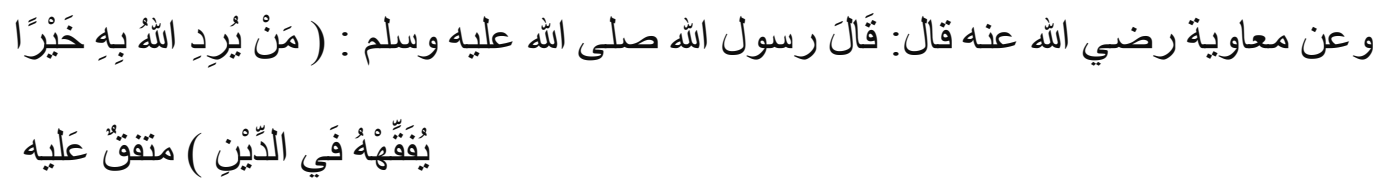

Dari Mu'awiyah r.a. berkata: Rasulullah Saw. Bersabda:" Barang siapa yamg dikehendaki oleh Allah untuk memperoleh kebaikan, maka Allah membuat ia menjadi pandai dalam hal keagamaan". (Mutafaq 'alaih)10

${ }^{10}$ Imam Nawawi, Terjemahan Riyadhus Shalihiin, jilid 1, hal. 97. 


\section{Nurul Hidayah, Khusnul Khotimah.}

Dalam hadist tersebut menunjukkan salah satu keutamaan ilmu agama yang paling besar. Dalam hadist tersebut juga menyebutkan, bahwa ilmu yang bermanfaat merupakan tanda akan keberuntungan seorang hamba, dan tanda bahwa Allah menghendaki kebaikan dengannya ${ }^{11}$. Fiqih yang dilandasi oleh keimanan yang kuat, akan mendorong peserta didik untuk mengembangkan pemahaman dan keyakinan tentang adanya Allah Swt. sebagai sumber kehidupan. Selanjutnya adalah pengamalan yang mengkondisikan untuk mempraktekkan dan merasakan hasil-hasil pengamalan Fiqih dalam kehidupan sehart-hari. Pelaksanaannya tentu dengan membiasakan melakukan tata cara ibadah, bermasyarakat dan bernegara yang sesuai dengan materi pelajaran Fiqih yang dicontohkan oleh para ulama.

Untuk dapat melaksanakan agama dan kepercayaannya dengan baik dan benar itu, maka diperlukan pendidikan agama khususnya Fiqih yang menjadi aturan dalam syariat Agama Islam secara berkesinambungan, mulai dari sekolah tingkat dasar sampai pada perguruan tinggi.Masuk dalam pemahaman agama ini adalah mendalami berbagai permasalahan akidah, dengan mengikuti jalannya kaum salaf serta mewujudkannya dalam kehidupan baik lahir maupun batin. Juga mengetahui mazhab-mazhab para penentang akidah tersebut, disertai dengan mengerti dari mana bentuk penentangannya terhadap AlQur'an dan Sunnah.

\footnotetext{
${ }^{11}$ Ramayulis, Ilmu Pendidikan Islam. (Jakarta: Kalam Mulia.2002), hal.145
} 


\section{KESIMPULAN}

Hasil dari analisis yang telah dipaparkan dalam bab sebelumnya, serta mengacu pada rumusan masalah yang telah disusun, maka dapat ditarik kesimpulan sebagai berikut: Materi Pembelajaran Agama Islam dalam dunia pendidikan menjadi salah satu unsur penting dalam proses pembelajaran seseorang. Karena, dalam Materi Pembelajaran Agama Islam mengajarkan tentang ilmu-ilmu keislaman. Dalam Materi Pembelajaran Agama Islam dibagi menjadi 3 materi yaitu (1). Materi Aqidah ialah materi yang menjelaskan, bahwa tempat meminta dan mengadu hanyala kepada Allah swt. (2). Materi Al-Qur'an ialah materi yang menjelaskan, tentang pengkajian membaca Al-Qur'an dan tajwid, sifat dan makhrajnya ma'na dan tafsirannya. (3). Materi Fiqih ialah materi yang menjelaskan tentang kaidah-kaidah Islam dan mengetahui halal dan haram, hukum-hukum mengenai ibadah dan muamalah. Maka dapat disimpulkan bahwa ketiga materi tersebut tidak dapat dipisahkan, karena pada hakikatnya matri Aqidah, Al-Qur'an, Fiqih itu sangatlah penting dalam hal kehidupan sehari-hari.

\section{E. DAFTAR PUSTAKA}

Akmansyah, M. (2015). Al-Qur'an dan Al-Sunnah sebagai Dasar Ideal Pendidikan Islam. Ijtimaiyya: Jurnal Pengembangan Masyarakat Islam, 8(2), 127-142.

Ali, A. M. (2018). Pendidikan Karakter: Konsep dan Implementasinya. Prenada Media. 


\section{Nurul Hidayah, Khusnul Khotimah.}

Harsah, N. J. (2019). Komunikasi Edukatif Dalam Keluarga Sakinah Di Kalimantan Selatan (Perspektif Penananan Nilai-nilai Pendidikan Agama Islam) (Doctoral dissertation, Pascasarjana).

Sukatin, S. (2018). Pendidikan Karakter dalam Prespektif Islam. NUR EL-ISLAM: Jurnal Pendidikan Dan Sosial Keagamaan, 5(2), 131-149.

Rahman, M. I. (2019). Pengentasan Buta Huruf Al-Qur'an di SMP Muhammadiyah 1 Sleman. Jurnal PAI Raden Fatah, 1(3), 277-293. 